\title{
Islamic-Based Mathematics Learning Management Model Development (Case Study at the State Islamic Senior High School 1 of Jakarta)
}

\author{
Faizah $^{1}$, Prof. Udin Syaefudin ${ }^{2}$, Oneng Nurul Bariah ${ }^{3}$ \\ ${ }^{I}$ Ministry of Religion Affairs of the Republic of Indonesia Jakarta, Indonesia \\ ${ }^{2}$ Saud, M.Ed., Ph.D., Universitas Pendidikan Indonesia \\ ${ }^{3}$ Oneng Nurul Bariah, Muhammadiyah University of Jakarta
}

\begin{abstract}
Mathematics is a science learned by all people since at an elementary school up to a university. Although mathematics has a very important position, some cases show that mathematics is still deemed as a subject difficult to study at school, and some students consider it as a subject not so exciting. This is why the study performance of mathematics is always very low compared to other subjects. Therefore it is necessary to develop an Islambased mathematics learning model. A learning model that can form student's character which is based on a mathematics learning being combined with Islamic values. This research is conducted at the State Islamic Senior High School 1 (MAN 1) of Jakarta. This research uses a Research and Development (R\&D) method. The result of this research shows a mathematics management model of the State Islamic Senior High School 1 (MAN 1) of Jakarta being conducted truly as follows: Plan, Teaching Material Development, Learning Practice, Learning Evaluation based on K-13. The Islamic-based Mathematics Learning Model is conducted properly with aspects of: Plan, Teaching Material Development, Learning Practice, K-13 Learning Evaluation plus Islamic values constituting one of types of nationality education. The Islamic-based Mathematics Education Management Model is effective in enhancing the quality as follows: Plan, Teaching Material Development, Learning Practice and Evaluation. The Islamic-based mathematics education management model has a very positive impact for teachers and students of the State Islamic Senior High School 1 (MAN 1) of Jakarta as well as puts forward the very good Islamic values being reflected and realized in daily life.
\end{abstract}

Keywords: Management, Mathematics, Islamic Integration

\section{INTRODUCTION}

$\mathrm{I}$ slamic education is an integral part of the national education the aim of which is to enhance the true belief to the Only One God. Law on National Education System Number 20 of 2003, states that national education shall be conducted for the purpose of developing competence and forming proper characters as well as civilization of the nation, educating the people to be smart in living the nation life, to be pious and believe the Almighty One God, to behave in a good manner, healthy, having knowledge and having the purpose of developing students' potential to become such creative and independent studentsand to become democratic citizen realizing their responsibility.
Education is very important to build a state or a nation. Education guarantees people's life survival. Education is not only about how to know and how to perform it, but also important on how to become, in order to become so it is necessary to transmit culture as the most important method.Bearing in mind the importance of issues related to education, it is necessary to set up an education standard, which constitutes the responsibility of the national education system. Bearing in mind that the national education system is of universal nature, inclusive and is conducted widely, then it is open for all people and covers the entire territory of the country, covering all directions, level and types of community.

One of such principles is that education is the process of students' continual civilization and empowerment. In this process, teachers must lead by giving examples, developing personality, as well as developing student's competence and creativity. The result of this principle is the change of paradigm in education process, learning model and learning paradigm. Development of a country is measured on how progressive education is achieved. Its situation is similar to a training machine displayed at school, apart from whether it is good for students or not. A clear fact is that in the entire education history in our country there is no such a very extraordinary and significant progress.

Related to such problems in education world, the education quality, especially graduate's quality, cannot be separated from the roles of directors, teachers, students, infrastructure and other factors which are depended and related one another. This learning process must be managed properly. Learning management influences the success or failure of a learning process, which indirectly influences its graduate's quality. Mathematics is one of a science discipline which determine graduate's quality.Mathematics is a subject being learned by all people since elementary school up to university. As we know, mathematics was arising due to human thought related to idea, process, and reasoning. Mathematics is deductive, not including generalization based on observation (inductive), but only generalization based on deductive evidence. This conclusion is the logical consequence of the facts, which base it. 
The importance of mathematics learning is not separated from its role in various aspects of life. Beside that, by learning mathematics someone will get used to think systematically, scientifically, logically, and critically which can enhance his/her creativity. Fasani said, mathematics is important as a tool, as a science (for scientists), as behavior silencer, and as a thinking pattern guide. Bearing in mind that mathematics is important in daily life, mathematics must also be understood and mastered by our generation in all layers of community, including school students.Mathematics covers a lot of related topics. Such relationship is not only amongst mathematics subjects, but also between mathematics and other disciplines and in daily life. In mathematics, there is a close relationship between one concept and another, not only from the subject point of view, but also from the point of view of the formulae presented. Besides that, mathematics subject, mathematics connection and daily life mathematics with other knowledgeare also called as mathematics connection. Thus, if someone learns mathematics, he/she learns to be connectedwith mathematics.

Although mathematics has such an important position, several cases show that mathematics is still deemed as a subject difficult to learn at school, and some students still consider it uncomfortable. This is why student's study performance of mathematics is always very low compared to other subjects. Such a poor study performance of mathematics is because of less activity in learning mathematics. When students follow the process of mathematics learning at school, they are bored with mathematics, they are not interested and they are too lazy to learn, because mathematics is deemed as pure science, which only comprises groups of numbers and formulae, whichcannot be used in daily life. They think that learning mathematics at school only teaches students on how to solve problems with better way, so that it increases their hate to mathematics subject.

Initial observation result shows that mathematics examination grade shows such a low category compared to the grade of other subjects. Therefore Islamic-based mathematics learning model should be developed. The learning model which can form student's character based on mathematics learning being combined with Islamic values.Islamic values are used as a base to improve student's attitude.If Islamic values are inserted in the learning process, and the learning process is conducted at an Islamic education institution, for example at Islamic school, this is very relevant because Islamic school is an Islamic education institution which combines religion knowledge and general knowledge. Therefore, if related to Islamic values at Islamic education institution for mathematics learning, it is very relevant and will make students learn mathematics enthusiastically.

Combination of mathematics and Islam is an education method which integrates Islamic values into mathematics material and give enriching experience to students. Integrated learning is considered meaningful because students understand the concept they learn by looking at it directly and connect it with other concept they understand. The State Islamic Senior High School 1 of Jakarta is an Islamic education institution combining Islamic values and general knowledge, therefore Islamic values are including in general education. From the above-mentioned background, the writer tries to conduct a research with title Islamic-based Learning Management Model (Case Study of Mathematics Learning Management at the State Islamic Senior High School 1 (MAN I) of Jakarta).

\section{PROBLEM FORMULATION (FOCUS AND SUB FOCUS OF THE PROBLEM)}

The formulation of this research problem is: How the mathematics learning management model at the State Islamic Senior High School 1 (MAN 1) of Jakarta. How the Islamicbased mathematics learning management model is. How the effectiveness of the Islamic-based mathematics learning management model in quality development is. How the impact of the Islamic-based mathematics learning management model at the State Islamic Senior High School 1 (MAN 1) of Jakarta is. Based on the formulation of the research problem, then what becomes the focus in this research is the Islamic-based mathematics learning management model at the State Islamic Senior High School 1 (MAN I) of Jakarta. Whereas the sub focus in this research is the Islamic-based mathematics learning management model seen from planning, implementation, and evaluation of the learning.

\section{A. $\quad$ Purpose And Benefit Of The Research}

The purpose to be achieved in this research is: To describe the mathematics learning management model of the State Islamic Senior High School 1 (MAN 1) of Jakarta. To formulate Islamic-based mathematics learning management model.To analyze the effectiveness of the Islamic-based mathematics learning management model in quality enhancement.To analyze the impact of Islamic-based mathematics learning management model at the State Islamic Senior High School 1 (MAN 1) of Jakarta.It is expected that the result of this research will give benefit for: The Regional Office of the Ministry of Religious Affairs of the Special Area of the Capital City of Jakarta Province, in order to give guidance to the Principal of Islamic schools and teachers in improving the quality of the Islamic-based mathematics learning management. The principal of Islamic schools should give direction to teachers in applying Islamic values in the process of mathematics learning.Teachers should be able to increase Islamic-based mathematics learning management. Students should apply Islamic values in school environment, in the community environment, and family environment.

\section{THEORETICAL STUDIES}

Management is the art of working through human (the art of reaching goal through human). Although experts have given a lot of definition about government which is in line with their point of view and approach. In his book, Made Pidartasaid 
that management is the center for the art of ruling, and management is started and ended by ruling other resources. Management is the central element of governing, management is the main part of setting and is responsible for most of the tasks in managerial decision. This is the core of management and the main activity of the controller center, central or cooperation to reach the goal having been set up amongst members of an organization. Sulisttorini's book The Administration of Islamic Education explains the following steps of individualto manage organization, or school institution in order to reach the goal of organization, institution or school effectively and efficiently. Siagian offers a definition of management as a competence or skill to reach a result in achieving the goal by means of other person's activity. Whereas Stoner calls it as a process: planning process, organization process, management, supervision, and directing the work of members of an organization and using all resources to reach such a goal. The term "Learning" is related to definition of studying and education. Learning is to learn and teach conducted at the same time. Teaching can be in progress without any teacher or without any other formal activity. Learning and teaching process is an interaction between teacher and students as well as source of study in a learning environment. In order that the education process becomes effective and efficient, then it must be planned, conducted, evaluated and monitored. Learning is one of the efforts in the human resources development which must be conducted continuously to the rest of life. The contents and process of education should be updated in line with the progress of social and cultural science. It means, if the Indonesian people and the people all over the world want to have talent nationally or internationally, then the content and process of education must focus on the achievement of such skill.

Sardiman said: "Studying is an intentionally effort to make use of education resources in order that education process will be proceeded for students.Mazur said learning is relatively enduring change observable behavior that occus as result of experience. On the contrary, cognitive learning theory sees that "studying is the change in somebody's mental structure which gives ability to reduce the level of behaviour change. Eggenand Kanchak said, the problem of mental structure is knowledge, belief, hope and other mechanism existing in student's personality. Thus, learning can bring a change occurring in student's personality, both cognitively, emotionally or psychologically.

Condition of learning is the factor influencing the method used by the teachers as the learning designer and must be accepted as it is. These variables are learning objective, learning contents; limited source of study, as well as student's characteristics.This learning management definition can be meant widely in the meaning that it covers the entire learning activities of the students starting from planning up to learning evaluation. From other perspective, learning management is the part of the learning management strategy.Learning management can also be defined as an effort to reach goal through someone else's activity or conducting what is conducted by other people in the form of student's interest, talent, entertainment and experience, widening the scope of activity (but not too limited) and is directed to the life future image development.

Therefore, it can be seen that learning management is an activity driving the learning process and therefore learning management is part of the series of activities in education management. In the learning management, the role of administrator is played by teachers. Therefore, teachers have authority and responsibility in various stages of management activities including planning, organizing, monitoring (leadership) and evaluation of education management. Based on the opinion and expertise of several professional mentioned above, the learning management concept can be divided into and limited widely. In its wider meaning, learning is the studying activity being designed to involve students in initiation activity, covering management process, planning, organizing, guidance, or evaluation. At the same time, teaching control in the narrow meaning is defined as an action to be conducted by a teacher and his/her students to study. Therefore, several things that should be taken into account when managing a learning among other things are: curriculum between teacher and students; policy learning; asset management; control devices; group study; medication and prevention program; as well as enhancing education quality.As part of the teaching management activity, teacher collects and integrates various resources into the teaching process with teacher and students, scientific helping tool and teaching, even when they integrate various resources available to reach the goal. According to Majid, in case of teaching, planning can be defined as learning preparation, the use of demonstration tools, the use of teaching method and technique, as well as evaluation of the time allocated to reach the purpose having been determined.

At the first activity, teacher prepares students' mental and physical to participate in the learning process; ask them questions about their knowledge in the past about such topic; describing the purpose of learning or precious knowledge they will get; teacher conveys the contents of a subject and explains the action complying with the program. Mathematics learning must be composed as such that involves students and encourage students to actively participate in the mathematics learning process. Therefore, learning mathematics shall mean to learn to understand and solve the problems related to the concept, principle, and facts of mathematics in daily life.According to Bruner, mathematics study shall involve not only to find the relationship between mathematics and its structure, but also the study on the concept and structure of mathematics in the material studied. Erman Suherman has an opinion that by learning mathematics, experience has helped students get accustomed to understand certain attribute rather than to become part of a lot of objects. 
Based on the description of the purpose of learning mentioned above, we can understand that mathematics is not about calculation, instead, students can overcome various problems of daily life better. Both problems are related to mathematics or other scientific problems and need more training because the concept of basic mathematics can be applied in daily life.Fathurahman and Sutiko put forward that integration of Islamic concepts in mathematics learning frequently conduct these following things: (1) calling the name of Allahthe Almighty God (2) use of words (3) visual description (4) its application or example. (5) related clause or mixed with the prophet's tradition (Hadits) (6) history invention (7) subject network and (8) symbol of religious kauniyahverses.

\section{RESEARCH METHODOLOGY}

In this research the writer uses Research andDevelopment (R\&D) method. According to Sugiano, the Research and Development method is then abbreviated as $\mathrm{R}$ and $\mathrm{D}$, namely a research method used to make certain product and to test the effectiveness of said product. The said product is not always presented in the form of hardware or tools and equipment such as books, writing utensil and other props. But can also be in the form of software. In its implementation, R and D method uses a number of descriptive method, evaluative and experimental. This research was done at the State Islamic Senior High School 1 (MAN 1) of Jakarta. The reason of choosing this school is because the State Islamic Senior High School 1 (MAN 1) of Jakartais one of the oldest Islamic Senior High School in Jakarta and has already got "A" accreditation which has already got the average mark of national examination of above average.

\section{THE RESULT OF RESEARCH AND ITS ELABORATION}

\section{D.1 The Mathematics Learning Management Model at the State Islamic Senior High School 1 (MAN 1) of Jakarta}

Mathematics Learning Planning at the State Islamic Senior High School 1 (MAN 1) of Jakarta.The first thing to be conducted by teachers in starting learning is to conduct a setting of place and to prepare students' psychological condition. The activities to be conducted by teachers in arranging classroom are:

Managing the seats to give comfortable situation in accordance with student learning activity, namely group.Studying activity can also be designed to be conducted outdoor (outdoor activities).

Drawings of formulae and progression are prepared.Psychological factor namely teacher who is hospitable, has positive attitude, enthusiastic to students in discussing mathematics learning material. Learning planning is the process to prepare teacher before conveying a lesson by measuring: (1) composing the learning tools, (2) explaining the learning objectives, (3) choosing/defining teaching material, (4) defining learning method, (5) setting up the learning media/tools, (6) evaluation tool arrangement, (7) time management, and (8) the making of student groups.

Mathematics Learning Tools at the State Islamic Senior High School 1 (MAN I)of Jakarta. The learning tools which must be composed by each teacher especially mathematics teachers at the State Islamic Senior High School 1 (MAN 1)of Jakarta shall cover the annual program, semesterprogram, syllabus and Learning Implementation Plan (RPP). According to the Principal of the State Islamic Senior High School 1 (MAN 1) of Jakarta, "teachers must have learning tools. This is a must for each teacher. The learning tools shall be proved with the availability of the Learning Implementation Plan (RPP)".Describing the purpose of the Mathematics Learning at the State Islamic Senior High School 1 (MAN I) of Jakarta. The purpose of learning shall be formulated as a skill to be achieved or mastered by the students by means of the learning objective. Teachers can design what to be conducted by the students after completing the learning process. Choosing and determining the mathematics Material at the State Islamic Senior High School 1 (MAN I) of Jakarta. Mathematics is a universal science which bases modern development, and plays important role in various discipline of knowledge as well as encourages human's thought. Therefore, mastering and creating a future technology need a strong mastering of mathematics since the very early age. To educate students to become technology experts, can make use of their knowledge in the life of managing the state and the nation, is not enough only by mastering its field of science purely, but also needs the role of the students in applying such an Islamic-based mathematics learning.

Determining the Mathematics Learning Method at the State Islamic Senior High School 1 (MAN I) of Jakarta. The mathematics learning method used can increase student's ability to think logically, critically, to work hard, to have curiosity, independence, and self-confidence. Teacher is an educator. Educator is an adult with all his/her competence to be able to change their students' psychological condition and thinking pattern from not knowing to become knowing as well as to make their students be adult persons. One of the things to be conducted by teacher is by teaching at a classroom. One of the most important things is teacher's performance at a classroom. How can a teacher control the classroom condition in order to create such a joyful learning atmosphere?Thereby a teacher must apply a learning method being appropriate with his/her students' characteristics.

Determining the Mathematics Learning Media at the State Islamic Senior High School 1 (MAN I) of Jakarta. Mathematics Learning Media can give a message, which can grow such a religious attitude, honesty, cleverness, toughness, care, and critical democratic attitude.In line with the competence insistence to be obtained by teachers (pedagogic competence, personal competence, social competence and profession competence), teaching material development (learning material) and media is one of teacher's obligation to develop his/her competence, in its turn can enhance his/her 
existence as a professional teacher. Composing Mathematics Evaluation Tools at the State Islamic Senior High School 1 (MAN I) of Jakarta. One of the functions of teacher profession is to evaluate all the activities conducted in the learning process. This origin from the fact that the two functions quantitatively and in its relationship with qualitative factor shall be in accordance with each person's curiosity of the shape, based on the activity result conducted. Thereby evaluation is one of the factors in education process, and its function and characteristics are not arguable anymore. In other words, evaluation activity is an inseparable part from the learning process. Allocating the Mathematics Learning Time at the State Islamic Senior High School 1 (MAN I) of Jakarta. The time allocation shall be arrangedin accordance with the characteristics of the material to be conveyed to the students, other than the effective time at each semester. To understand teacher's perception on how the time is allocated, the researcher conducted an interview with informant.

D.2 Mathematics Learning Material Development at the State Islamic Senior High School 1 (MAN 1) of Jakarta.

Learning material is the main material, which must be learned by the students to have a basic competence. The material of this learning is described from basic competence. If basic competence is formulated in the form of verbs, then learning materialis formulated in the form of nouns, or verbs being made as nouns.In this research, the development model used is the ADDIE development model comprising 5stages, namely analysis, design, development, implementation, and evaluation. In each stage there are several activities to be conducted.

D.3 Implementation of the Mathematics Learning at the State Islamic Senior High School 1 (MAN 1) of Jakarta.

Based on the RPP made, mathematics teachers of the State Islamic Senior High School 1 (MAN 1)of Jakarta in implementing mathematics learning activity shall cover three phases of activities, namely introduction activity phase, core activity phase, and closing activity phase.Using the Method. By using the proper method, it will also determine the effectiveness and efficiently of teaching, to increase students' activity and creativity it is necessary to conduct a selection and development of the teaching method. Teachers should understand the teaching method to teach effectively and enhance students' proficiency. Using Learning Media. Learning tools are integral parts of the learning in this field. The use of teaching material is the creative and systematic efforts to create such an experience which facilitate the interaction between teacher and students for more effective and efficient learning activity.Concluding the Lesson.At the last or closing activity, teacher shall finish the topic, give feedback, evaluate, plan the next activity, give assignments, and complete the lesson. Mathematics Learning Evaluation at the State Islamic Senior High School 1 (MAN 1)of Jakarta.Evaluation Phase is the students' understanding evaluation phase of such a topic. The purpose party such a test is to know whether measurement has been reached at the teaching material.

D.4 Islamic-based mathematics learning management model at the State Islamic Senior High School 1 (MAN 1)of Jakarta

The Islamic-based mathematics learning planning at the State Islamic Senior High School 1 (MAN 1)of Jakarta.The Islamicbased Mathematics Education Plan is the preparatory process conducted a mathematics teacher before starting an education, starting from (1) preparing learning tools, (2) describing the purpose of education (learning), (3) choosing/defining education (learning) material, and (4) determining the learning method. (5) Choosing education (learning) media/tools, (6) composing evaluation tools, (7) time allocation and (8) student group formation. Islamic-based mathematics learning equipment.Islamic-based mathematics learning equipment to be developed by each teacher especially mathematics teacher of the State Islamic Senior High School 1 (MAN1) of Jakarta is the Learning Implementation Plan (RPP).

Describing the purpose of the Islamic-based mathematics learning.The purpose of the learning being formalized is the purpose of learning for one time meeting and is formulated based on core/basic competence. The purpose of learning is formulated in the form of competence to be achieved or mastered by students by means of the purpose of the learning. Teacher can predict what to be achieved by the students at the end of learning process. Choosing and setting up the Islamicbased mathematics material. Description of material shall be written based on the core material,and the core material shall be determined in accordance with basic competence. The material discussed in this research shall be a group of lines and a group of sequence. The verses in the Al-Quran related to this material comprising: (a) Q.S. Al-Fatirverse 1, ( b) Q.S. Al-Mujadilah, verse 7, (c) Q.S Al-Muzzammil verse 20 and (d), Q.S Al-Kahfiverse 22. Description of material must cover the facts, concept, principle and operation in mathematics. Determining the Islamic-based mathematics learning method.

Discussion according to mathematics teacher is a scientific conversation amongst several persons joined in such a group to exchange their own view on such a problem or jointly finding a solution for the truth of such a problem. Determining a Learning Media.Mathematics learning media can convey a message which can put forward religious values, honesty, cleverness, endurance, consideration, and democracy.Composing the Islamic-based mathematics learning material evaluation tools.The Islamic-based mathematics learning material evaluation tools can be in the form of discussion method evaluation instrument.

The Islamic-based mathematics learning material development at the State Islamic Senior High School 1 (MAN I) of Jakarta. In the development of the Islamic-based textual book development, the State Islamic Senior High School 1 (MAN 1) of Jakarta uses the ADDIE management model comprising five stages namely analysis, design, development, 
implementation and evaluation. In each step, we should conduct several steps. Implementation of the Islamic-based mathematics learning at the State Islamic Senior High School 1 (MAN 1) of Jakarta. Presenting the Islamic-based mathematics learning material on the subject matter of lines and sequence.Evaluation of the Islamic-based mathematics learning at the State Islamic Senior High School 1 (MAN 1) of Jakarta.

The effectiveness of the Islamic-based mathematics learning management model in the quality development at the State Islamic Senior High School 1 (MAN 1) of Jakarta. The effectiveness of the Islamic-based mathematics learning planning,the effectiveness of Islamic-based mathematics learning material development, the effectiveness of implementation of Islamic-based mathematics learning, the effectiveness of evaluation of Islamic-based mathematics learning. The impact of the learning model being conducted can form students' better character namely friendship values, honesty, openness, and better believe in God the Creator.

\section{CONCLUSION}

Based on the research result, the Islamic-based mathematics education management development is:the Islamic-based mathematics learning management model at the State Islamic Senior High School 1 (MAN 1) of Jakarta shall be conducted properly as follows: (a) Plan, b. Teaching material development, c. Learning practice d. Learning evaluation based on K-13.The Islamic-based mathematics learning model shall be implemented properly with aspects as follows:a. Plan, b. Teaching material development, c. Learning practice d. Learning evaluation led by K-13 plus the Islamic values constituting one of types of national education, and Indonesian personality noble values.The Islamic-based mathematics education management model is effective in enhancing the quality as follows: a.Plan, b. Teaching material development, c. Learning practice d. Learning evaluation.Islamic-based mathematics education management model has a positive impact for teachers and students of the State Islamic Senior High School 1 (MAN 1)of Jakarta as well as put forward the Islamic values being reflected and embodied in daily life.

\section{SUGGESTION}

Based on the conclusion, we can give suggestion as follows:to the teachers, they should better improve the Islamic-based mathematics learning management model at the State Islamic Senior High School 1 (MAN 1)of Jakarta seen from: (a) planning, b. material development, c. learning implementation, and d. learning evaluation. To the teachers, they should better enhance the Islamic-based mathematics learning management model seen from: (a) planning, b. material development, c. learning implementation, and $\mathrm{d}$. learning evaluation. To the teachers, they should better increase the effectiveness of the Islamic-based mathematics learning management model seen from: (a) planning, b. material development, c. learning implementation, and $\mathrm{d}$. learning evaluation. The impact of the Islamic-based mathematics learning management model should be better increased especially to the students at the State Islamic Senior High School 1 (MAN 1) of Jakarta.

\section{CONTRIBUTION / ORIGINALITY}

This study contributes to the existing literature by analysing an Islamic-based mathematics education management model and its impact for teachers and students which puts forward the very good Islamic values being reflected and realized in daily life.

\section{REFERENCES}

[1] Abdul Halim Fathani,2009. Mathematics, Essence and Logic. Yogyakarta: Ar-Ruzz Media.

[2] Abdul Majid,2011.Learning Planning: Developing Teacher Competence Standard. Remaja Rosdakarya. Bandung.

[3] Anonim, being accessed on the $25^{\text {th }}$ of March 2015 at 20.28 hours. Learning Theory.http://skj6bbb. Edu. ms/additional source/THEORY. HTM.

[4] Anonim, being accessed on the $20^{\text {th }}$ of July 2015 at 20.03 hours.Mathematics Learning Technique, dalam www.Innovative mathematics learning technique html.

[5] Arifin, Zaenal,2011.Learning Evaluation: Principle, Technique, Procedure. PT Remaja Rosdakarya. Bandung.

[6] Arismunandar,2006. Education Management:Opportunity and Challenge. Makassar State University, Makassar.

[7] Bafadh, Ibrahim,2004.Fundamentals of Kindergarten Supervision Management, Bumi Aksara, Jakarta.

[8] Baharuddin and Moh.Makin,2010. Islamic Education Management. Malang:UIN-Maliki Press. Malang.

[9] Darmaningtyas,1994.Education In the Era of Crisis and Afterwards (Education Evaluation in the Era of Crisis). Jogjakarta : Pustaka Pelajar.

[10] Department of National Education, 2003. Curriculum of 2004 Competence Standard of Mathematics Subject at Senior Secondary High School and Islamic Senior Secondary High School, (Jakarta: Depdiknas).

[11] Department of Religious Affairs of the Republic of Indonesia,2009. Al Qur'an and Its Translation, (Bandung: PT Sygma ExamediaArkanluma).

[12] Directorate of Junior Secondary Education,2003.Contextual Approach (Cotextual Teaching and Learning/CTL).Department of National Education -Directorate General of Primary and Secondary Education - Directorate of Junior Secondary Education. Jakarta.

[13] Eggen, P. andKauchak, Deed,1997.Educational Psychology. Prentice-Hall. Colombus.

[14] Eka Prihatin,2011.Student Management,Alfabeta, Bandung.

[15] E. Mulyasa, Competence-basedCurriculum: Concept, Characteristics and Implementation.

[16] Erman Suherman et. al.,2003.Contemporary Mathematics Learning Strategy, (Jica, Revision Edition).

[17] Fatih Arifah, Yustisianisa,2012. Learning Evaluation (Jakarta: Mentari Pustaka).

[18] Fathurrahman, P dan Sutikno, S, 2009. Learning and Teaching Strategy through General Concept and Islamic Concept. Bandung : Refika Aditama.

[19] H.M. Ali Hamzah, Muhlisrarini, Mathematics Learning Planning and Strategy.

[20] Made Pidarta,2002.Indonesian Education Management, Jakarta: Rineka Cipta.

[21] M. Arifin, 1993. Islamic Education Philosophy, (Jakarta : Bumi Aksara).

[22] Muhaimin, Abd. Mujib, 1991. Islamic Education Thinking, (Bandung : Bumi Aksara). 
[23] Maimun, Agus,. Fitri, Agus Zaenal,2010.Superior Islamic School of Alternative Education Institution in the Competitive Era, UIN Maliki Press, Malang.

[24] Haidara Putra Daulay, 2009.Islamic Education Dynamics in Southeast Asia, Jakarta: Asdi Mahasatya.

[25] Malayu S.P. Hasibuan, 2011. Management: Basic, Definition, and Problem, BumiAksara, Jakarta.

[26] H.M. Ali Hamzah, Muhlisrarini,2003.Mathematics Learning Planning and Strategy, Bandung:UPI.

[27] H, Martinis Yamin \& Maisah,2012. Classroom Learning Management: Strategy of Improving Learning Quality, (Jakarta: Gaung Persada Press).
[28] Hamalik, Oemar,2001.Curriculum and Learning. Jakarta: Bumi Aksara, Jakarta.

[29] Hamalik, Oemar, 2010. Curriculum Development Management.Remanja Rosdakarya, Bandung.

[30] Harjanto,1997.Teaching Planning. Jakarta : Rineka Cipta. Jakarta.

[31] Hasibuan, S.P. Melayu,2008.Basic Management, Definition, and Problem.Revision Edition. PT. Bumi Aksara. Jakarta.

[32] Herman Hudojo, 1988.Teaching and Learning Mathematics, (Jakarta). 